Accepted

10. 11.2020

Revised

20. 01.2021

Published

30. 06. 2021

Keywords requirements for procedural judicial documents, quality of procedural documents, enforcement proceedings, judgment, ruling, enforcement title

\section{TWO-TIER SYSTEM OF JUDGMENTS AND ORDERS (NATURE OF THE SEPARATE ORDER to Pay or Fulfil the Claim)}

\author{
MYKOLAS KiRKUTIS, REMIGIJUS JOKUBAUSKAS, \\ DARIUS BOLZANAS \& VIGINTAS VISINSKIS \\ Mykolas Romeris University in Vilnius, Vilnius, Lithuania \\ E-mail:mkirkutis@gmail.com,remigijus@jokubauskas.org, \\ darius.bolzanas@icloud.com,vigvis@gmail.com \\ CORRESPONDING AUTHOR \\ mkirkutis@gmail.com
}

\begin{abstract}
The quality of procedural judicial documents is one of the most important components of judicial proceedings. The trust of individuals and the public in the judicial system may also depend on the quality of these documents. Therefore, Lithuanian legislation sets certain standards for procedural judicial documents. As well as, the law also provides for certain possibilities to eliminate ambiguities in court procedural documents both after the court decision has been made and during enforcement proceedings.
\end{abstract}




\section{$1 \quad$ Introduction}

It is critically important for all states to strive to achieve the highest quality legal systems possible. When measuring the excellence of a legal system, one constituent element is the quality of the states' court decisions in the broadest sense. Although, the quality of justice is a product of a certain system consisting of judges and court staff and other participants in the proceedings (defenders, lawyers) qualifications, as well as the quality of individual court proceedings (from the adoption of decisions to execution proceedings). ${ }^{1}$

In the last decade in Lithuania much attention has been paid to the quality of procedural documents. The Code of Civil Procedure of the Republic of Lithuania (hereinafter: CCP) establishes three main court documents in civil litigation: i) a court order; ${ }^{2}$ ii) a court judgment; ${ }^{3}$ and iii) an execution order. ${ }^{4}$ These three main court documents are prerequisites for the exercise of the right to a fair trial. In order to guarantee the right to justice, judicial documents must be served in accordance with certain requirements. Some requirements of these documents discussed in this article justify their interdependence and commonality in civil proceedings.

This article consists of three parts. The first part analyses the requirements for the form and content of both a court order and a court judgment ${ }^{5}$ as well as the quality of these documents. We will address the procedure for issuing a court order together with the requirements for not only its content but also its enforceability. Secondly, we will delineate the content requirements for court decisions ${ }^{6}$ set out in both legislation and case law and the principles for quality of court decisions set out in the Recommended Quality Standards for Procedural Decisions Rendered by Courts (hereinafter: Standards).

\footnotetext{
${ }^{1}$ Jean-Paul Jean „La qualité des décisions de justice au sens du Conseil de l'Europe“, $8^{\text {th }}$ and $9^{\text {th }}$ of March, 2007. Colloquium organized by the Faculty of Law and Social Sciences of the University of Poities on the quality of court decisions. CEPEJ Study No. 4.

${ }^{2}$ It is an enforceable document issued by a court for the award of pecuniary claims, the entry into force of which depends on the will of the debtor (objections).

${ }^{3}$ It is an individual act of application of the law by which the court finally settles a dispute between the parties.

${ }^{4}$ It is a court document issued on the basis of a final and enforceable court judgment, which can be submitted to the bailiff for execution.

5 The CCP of the Republic of Lithuania regulates that in resolving a dispute, in principle, the court of first instance makes a court judgment. Meanwhile, the procedural issues arising during the proceeding are resolved by a court ruling. By court ruling, the court does not resolve the dispute on the merits, except in cases of appeal and cassation. 6 The term "court decisions" is used to refer to both a court judgment and a court ruling.
} 
The second part of this article analyses the nature of an execution order and the differences between the enforcement of court orders and court judgments. In the third part of this article, the authors discuss the judiciary's role within the hierarchy of the enforcement process as well as the peculiarities of the enforcement of some decisions.

\section{Court orders and judgments in civil litigation}

The CCP establishes that a claimant has the right to choose between several forms of civil litigation. One of these forms is a summary procedure and the other is a contradictory procedure. In Lithuania, there are basically three forms of summary proceedings - the court order procedure, the documentary process and the small claims procedure. This article focuses on court orders issued in summary proceedings and decisions made in the course of the litigation process. Therefore, in this part of this article, it is first of all expedient to explain the summary proceeding and the specifics involved in the issue of court orders.

\subsection{The requirements and nature of court orders}

Chapter XXIII of the CCP regulates the peculiarities of a court order. The court issues an order according to the creditor's statement of pecuniary claims arising out of the contract, tort, employment relationship, maintenance award etc. Article 431 (2) of the CCP identifies certain exceptions when an order cannot be issued. For example, the court may not consider the creditor's application for an order if (i) at the time of the application for a court order, the creditor has not fulfilled his obligation (or part thereof) to the debtor, for which a payment is demanded, and the debtor demands the fulfilment of said obligation; or (ii) when the debtor resides abroad or is domiciled abroad; or (iii) when the debtor's place of residence and place of work are unknown; or (iv) it is impossible to perform the obligation in parts and the creditor demands to perform the obligation of debtor in part.

The difference between a court order and a court judgment is that in court order cases, the court does not check the validity of the creditor's claim. The main purposes of a court order are both to simplify and expedite the work of the court in cases when the parties do not dispute the claim. When issuing a court order, the court only verifies that the creditor's application satisfies form and content 
requirements and that none of the circumstances set in Article 431 of CCP exist that would preclude the court from issuing the order.

How the matter proceeds depend on the nature of the debtor's objections, ${ }^{7}$ for which the debtor does not have to provide underpinning arguments. If objections are raised then the case is pursued further, if not then the court order enters into force and becomes an enforcement title. No further enforcement order is issued on the basis of the court orders since the court order itself is an enforcement title.

The case-law of the Supreme Court of Lithuania clarifies that the debtor's objection expresses his will to disagree with all or part of the creditor's claim, as the objection does not allow the injunction to take effect, which means that the court order proceeding ends and the creditor can defend its legitimate interests only by bringing an action in accordance with the procedure laid down in the CCP. ${ }^{8}$ As the court order is also an enforcement title, it must satisfy the requirements for an enforcement title. These requirements are discussed in detail in the next part of this article. A final court order has the same consequences in terms of enforceability as a final court judgment. ${ }^{?}$

A final court order, theoretically, acquires the force of res judicata, becomes a binding, indisputable and enforceable court document. In practice, however, there are possible situations where the court renews the time limit for lodging objections after the court order has already been enforced and annuls the court order. In such a case, when the court order is executed, the institution of reversal of the court judgment may also be applied. ${ }^{10}$

\subsection{The requirement and nature of court decisions}

The requirements for court decisions are established in the CCP, case-law and the Standards, which were approved by Resolution of the Judicial Council on 27 of May, 2016. Although, the Standards are recommendations and not binding, the courts of Lithuania apply them consistently.

\footnotetext{
${ }^{7}$ According to Article 439 (2) of the CCP, the debtor must submit all objections to the court within 20 days from the date of service of the notice of an issued court order.

${ }^{8}$ The Supreme Court of Lithuania 18.04.2014, Case No. 3K-3-222/2014.

9 The Supreme Court of Lithuania 01.12.2015, Case No. 3K-3-638-378 / 2015.

10 Supra note 3.
} 
Article 116 (1) of the CCP defines court documents as documents issued by the court during a trial. This article provides a list of court documents that can be issued by the court: i) judgments; ii) commandments; iii) orders; iv) rulings; v) resolutions; vi) minutes of court hearings; vii) summonses; and viii) notices. Sections 1 and 2 of Chapter 15 of the CCP regulate the essential requirements for courts' judgments and rulings.

Judgments differ from court orders. By rendering a judgment, the court resolves a dispute between the parties on the merits. If the court judgment fails to satisfy the requirements established either by legislation or case-law, according to Article 329 (2) of the CCP it can be annulled on the absolute grounds of invalidity or for failure to disclose the substance of the dispute. Thus, court decisions have to comply with the established requirements.

The Constitutional Court of Lithuania has indicated that a final judicial act rendered in a given case is a single act of application of law which settles the dispute. Thus, a final court act consists of one document, and not several legal acts - documents, written and rendered at different times. The final judicial act cannot be fragmentary. ${ }^{11}$ This means that the main requirement for court judgments, which derives from the Constitution of the Republic of Lithuania (hereinafter: Lithuanian Constitution), is that a court decision must be written in a one legal document (judgment or order).

In one case, the Supreme Court of Lithuania annulled the ruling ${ }^{12}$ (It. nutartis) and the additional judgment of an appellate instance court because of breach of the principle of continuity of proceedings. ${ }^{13}$ The appellate instance court examined the plaintiff's appeal and rendered a ruling without examination of the defendant's appeal. The court ruled on the defendant's appeal in an additional judgment. The Supreme Court found that the appeal court violated the fundamental rules of civil procedure, which are important for the correct resolution of the case because of the hypothetical possibility that if the appellate court had examined the appeals of both parties and established the circumstances relevant to the case prior to the

\footnotetext{
11 The Constitutional Court of Lithuania 21.09.2006.

12 Supra note 5.

13 The Supreme Court of Lithuania 19.04.2019, Case No. e3K-3-114-1075/2019.
} 
announcement of the court's final act, the examination might have led to a different outcome.

The content requirements of judgments can vary depending on the instance of the court. Article 270 of the CCP, for example, sets the content requirements for judgments rendered by the first instance court, while Article 331 of the CCP regulates the content requirement for judgments of appellate instance courts. Both Articles state that a court judgment consists of four parts: i) introductory part; ii) descriptive part; iii) motivation part; and iv) operative part. The introductory part of the decision of a first instance court shall specify the time and place of the decision, the name of the court which made the decision, the composition of the court (name and surname of the judge (s)), the secretary of the court hearing, the parties, other persons participating in the case and the subject matter of the dispute. The descriptive part of the decision of the first instance court must contain a summary of the parties' claims and objections. The statement of reasons for the decision must state in brief the circumstances of the case established by the court, an assessment of the evidence on which the court's findings are based, the arguments for which the court rejected any evidence, as well as the other legal arguments, legislation and other legal acts on which the court was guided. The operative part of the judgment of the first instance court must contain a court's conclusion to satisfy the claim and/or counterclaim in full or in part, together with the content of the satisfied claim, or to dismiss the claim and/or counterclaim, in cases provided by law - the amount of interest awarded and the period until which it is recovered, an indication of the costs of litigation, and court conclusions on other issues resolved by the decision. The operative part of the judgment of the first instance court also must state the time limit and procedure for appealing against the decision.

Article 291 of CCP regulates the content of the first instance court rulings ( $l$ t. nutartis). For comparison to the content requirements of court decisions, there is no requirement that an order of the first instance court must consist of four parts. Article 291 (1) of CCP stipulates that the ruling shall specify: i) the time and place of the ruling; ii) the name of the court; iii) the composition of the court and the clerk of the court; iv) the persons involved and the subject matter of the dispute; v) the issue on which the order is made; vi) the grounds on which the court reached its conclusions; vii) the ruling of the court; and viii) the time limits for appealing against the ruling. 
The introductory part of the appellate court judgment (ruling) ${ }^{14}$ must include the time and place of the judgment (ruling), the name and composition of the court that issued the judgment (ruling), the persons who participated in the proceedings before the appellate court (in oral proceedings), the appellant, the appealed court judgment (ruling), the main parties to the proceeding, the other parties to the proceedings and the subject-matter of the dispute. The descriptive part of the judgment (ruling) must briefly summarize the circumstances of the case, indicate the essence of the appealed judgment (ruling), the grounds of appeal and arguments of the response relevant to the legality and validity of the appealed judgment (ruling), and indicate the summary of the appeal.

Article 331 (4) of the CCP requires that the reasoning part of a judgment (ruling) of an appellate instance court shall set out in a concise form the circumstances of the case established by the court, the evidence on which the court's conclusions is based, the arguments upon which the court rejected any evidence, and the laws and other legal acts and legal arguments upon which the court based its conclusions. The operative part of the decision (ruling) must state only the decision of the court of appeal. Whereas the judgment (ruling) of the appellate court enters into force from the day when it is rendered, there is no requirement that the operative part of the judgment (ruling) delineates the terms and procedure for appealing against the decision. However, this does not mean that the judgment (ruling) of the appellate court cannot be appealed to the Supreme Court of Lithuania. ${ }^{15}$ The question therefore arises whether the requirement to explain to parties of the case the procedure for appealing against such a judgment (ruling) in the operative part of a judgment (ruling) should not also apply to judgments (rulings) of the appellate court. We believe, that this requirement is also applicable to the operative part of judgments (rulings) of the appellate court.

\footnotetext{
14 According to Article 326 (1) The court of appeal shall, after examining the case, have the right: 1) leave the judgment of the court of first instance unchanged; 2) set aside the judgment of the court of first instance (in whole or in part) and adopt a new judgment; 3) change the judgment of the court of first instance; 4) annul the judgment of the court of first instance in full or in part and refer the case to the court of first instance for retrial; 5) set aside the judgment of the court of first instance (in whole or in part) and dismiss the case or leave the application unexamined. Then the court of appellate instance adopts a new judgment the court document - judgment - has to be rendered. In all other cases, court rulings are issued.

15 According to Article 345 (1) of the CCP, an appeal in cassation may be filed within three months from the date of entry into force of the appealed decision. An appeal in cassation against an order of an appellate court made on absolute grounds for invalidity of a decision shall be lodged within one month from the date on which the order under appeal enters into force.
} 
Nevertheless, these content requirements for the court decisions are minimum requirements and according to special forms of judgment the CCP can set additional requirements. For example, the motivational part of the judgment in absentia can be abbreviated (Article 286 (1) of CCP), whereas the introductory part of the judgment in absentia must specifically state that the decision was rendered in absentia (Article 286 (2) of CCP).

Certain requirements regarding the content of judgments (rulings) are also provided in case-law. According to the Constitutional Court of Lithuania, the requirement of the integrity of a final court act arising from the Constitution means that the operative part of such act must always, without any exceptions, be based on the circumstances and arguments expressis verbis set out in the descriptive and/or motivational parts. The Lithuanian Constitution does not tolerate a legal and factual situation where a final court act (judgment, ruling, etc.) is not formally rendered and made public, inter alia, when the operative part of such act is formally rendered and made public (which sets out the decision in principle) and the arguments in support of it (i.e. the judgment set out therein) are set out later, post factum.

Article 6 (1) of the Convention for the Protection of Human Rights and Fundamental Freedoms requires national courts to examine in detail the explanations, arguments and evidence provided by the parties without first assessing whether they are relevant to the decision. Judgments of courts and tribunals should duly state the reasons on which they are based. The statement of reasons for the decision is necessary in order to demonstrate that the parties have been heard and that justice has been done. ${ }^{16}$ According to Article 329 (2) (4) of the CCP, the court or tribunal's failure to provide such reasons (arguments) constitutes an absolute ground to invalidate a judgment or ruling. The mere insufficient reasoning of a court judgment (ruling), on the other hand, does not constitute an absolute ground for its invalidity under the ССР. In cases where the reasoning for the court judgment (ruling) is incomplete or insufficient, such violation may nevertheless be recognized as substantial if the main (essential) factual and legal aspects of the case are not answered in the reasoning of the judgment (ruling) and as a result the case could have been resolved incorrectly.

${ }^{16}$ ECtHR 27.09.2001, Case Hirvisaari v. Finland, No. 4968/99. 
The operative part is based on the arguments set out in the reasoning and not vice versa. Ensuring both the integrity and consistency of the judgment (ruling) is paramount. In the absence of a descriptive part, there can be no statement of reasons, and consequently there can be no operative part of the decision.

Thus, before its announcement, a judgment or a ruling shall include all four parts and its entirety must be signed either by the judge or the panel of judges. This requirement ensures that the judgment or ruling will not be supplemented after the announcement.

The Supreme Court of Lithuania has found that the reasoning and the operative part of the judgment must be interpreted in the light of the nature of the judgment as a single act. ${ }^{17}$ This means that the four parts of a court decision cannot be interpreted separately. When there are certain ambiguities in any of the four parts of the judgment (ruling), if possible, these ambiguities shall be resolved by interpreting the decision as a whole, considering all four parts of the judgment (ruling).

In some cases, the reasoning of the judgment may not be sufficiently clear and the court may be asked to explain the reasoning after the announcement of the judgment. Article 278 of the CCP regulates the institution of the interpretation of judgments (ruling). However, interpretation of the judgment (ruling) shall be permitted if it has not already been executed, or if the period during which the decision may be enforced has not expired or has not been renewed. ${ }^{18}$

The CCP regulates only the main content requirements for judgments or orders. The quality requirements for court judgments and orders are set out in the Standards.

\footnotetext{
17 The Supreme Court of Lithuania 08.02.2011, Case No. 3K-3-42/2011.

18 According to Article 606 (2) of the CCP, the general time limit for the submission of an enforcement order is five years from the date of entry into force of the decision. The time limit for lodging enforcement orders under urgent judgments is calculated from the first day after the judgment is given.
} 


\section{Requirements for court decisions in the context of Standards}

The Council of Judges decided to adopt the Standards, taking into account that the rule of law principle enshrined in the Lithuanian Constitution means that court decisions must be both duly motivated and clear. The fact that only reasoned court judgments can ensure a quality system of justice led to an initiative to ensure the quality of court decisions. The standard sets out seven principles for the quality of court decisions that are recommended to be followed when preparing judgments or rulings.

The first principle of the quality of court decisions is that the judgment must be fair and lawful. To satisfy this principle, the judgment shall be substantiated by the relevant factual circumstances (merits) of the case established by the court and by the law. This principle also requires the court to follow the applicable precedents in similar cases. Deviations from the precedents are permissible only in exceptional cases.

The court judgment shall be convincing. This means that the court decision should convince the interested parties that it is fair and lawful. In considering matters related to establishing factual circumstances, the court shall specify why it is rejecting certain evidence. Since in many instances the court decision will not be convincing to those to whom it is unfavourable, it is critical that sufficient attention shall be devoted, in the reasoning part of the decision, to the evaluation of the argumentation presented by the losing party. It has to be evident from the court decision why adopting the argumentation or position of the losing party would contradict legal provisions or evidence collected in the case. In providing arguments for its decision, the court may accept one or more arguments advanced by a participant in the proceedings, already stated in the decision, without repeating them. However, it must be evident that the court has made an independent evaluation.

The principle that courts decisions must be transparent means that the court shall state all the factual circumstances established that are relevant to the rendering of the decision, and all the motives underlying the decision, even when not all of the arguments are of a legal nature. The reasoning underlying the court decision shall be concise, clear, logical, unequivocal, specific, objective and unbiased. Where the court has seriously considered a number of alternative options in formulating its decision, 
they shall be set out in the reasoning part of the court decision, with all "for" and "against" discussed.

The court decision shall be consistent and sufficiently reasoned. Consistency of a court decision means that there is a logical relationship between different parts and paragraphs of the decision. All relevant factual circumstances shall be established and all legal issues shall be resolved in a reasonable sequence. The reasoning set out in the court decision shall not be contradictory. Sufficiency of the reasoning of the court decision means that explicit answers to the main issues raised in the case must be provided. The reasoning of the court decision shall demonstrate that the court considered all submitted evidence and dealt with all relevant questions/issues arising from the case.

Another principle of quality of court decisions is that a court decision shall be clear and understandable. The court decision shall be written in easily understandable, common Lithuanian language. Scientific, technical, artistic or other special terms should be used as rarely as possible or be explained. The wording of the operative part of the court decision shall be clear. In cases where the decision can be enforced, the operative part shall be worded in a way which makes it clear how the decision will be enforced. The court must render a decision that it would be possible to enforce in practice. The order of the court set out in the operative part of the court decision shall not give rise to opportunities for different interpretations of the content of the court decision in terms of how specifically and to what extent it should be enforced.

Further, a court decision shall have a clear structure and form and shall be correct both linguistically and legally. It shall be written without linguistic or spelling mistakes, consistently and in the same style. Structural parts that are required by law or that have been selected by the court (in cases where a statutory structural part is divided additionally by the court) must be clearly separated. Each paragraph in the decision should deal with an independent (new) thought/idea or other relevant information. Normally, a paragraph of the reasoning part of the court decision should not consist of just one sentence or two sentences. However, paragraphs should not be too long either (normally, maximum 0.5 of the page). 
The final principle is that a court decision rendered by a court of relevant instance shall reflect the peculiarities of the court of such instance. This means that decisions rendered by courts of first instance and courts of appeal shall be, first of all, clear and understandable to parties to the case, therefore, preparation of decisions shall take account of who are the parties, are they capable of understanding the content of the reasoning of the court, whether they receive professional legal aid. The main task of the court of first instance shall be to clearly define and identify the factual circumstances established by the court. Attention should be focussed on evidence as well as its summarisation, grouping and assessment. A legal assessment of the factual circumstances established by the court (qualification of relations) shall be presented, specifying those legal provisions which, in the opinion of the court, are applicable based on the factual circumstances, and the application of these provisions shall be substantiated. The higher the instance of the court, the greater the importance of law interpretation and development. Legal matters considered in a decision of a court of appeal as well as the relevant solutions and arguments shall be clearly identifiable and separable from other information.

These seven principles of quality of court decisions set forth in the Standards harmonized the form of court decisions in Lithuania. Nevertheless, even when these principles are fully satisfied, giving the decision the highest quality, the court decision nevertheless is meaningless if it is not enforceable.

\section{The enforcement of court judgments and orders: the nature of the enforcement title}

The right to a fair trial depends not only on the efficiency of court proceedings and on the quality of court decisions, but also on the effectiveness of the enforcement proceedings. Applicable case law of the European Court of Human Rights suggests that enforcement proceedings are an integral part of the right to a fair trial. ${ }^{19}$

${ }^{19}$ ECtHR 19.03.1997, Case Hornsby v. Greece, No. 18357/91. 
Although no material value is created in the enforcement process, nevertheless the court decision is enforced and the amount decided by a court or other competent entity is recovered. The practical form of expression of this judgment in enforcement proceedings is an execution title issued by the court (Višinskis and Stauskienè, 2007: 58). ${ }^{20}$

Article 586 of the CCP states that the basis for the execution of enforcement actions is an enforcement title submitted for execution in accordance with the procedure established in the CCP. Enforcement actions taken without an enforcement title are prohibited, with certain exceptions, such as where the judgment itself is considered to be an enforcement title (for example, a court order on interim measures etc.)(Višinskis and Stauskienè, 2007: 59-60). When performing enforcement actions, the bailiff must unconditionally comply with all of the enforcement procedures set forth in the enforcement title since it is the enforcement title itself that determines both the scope and the content of enforcement proceeding. ${ }^{21}$ Therefore, the enforcement title must also meet certain content requirements.

Article 648 of the CCP sets the parameters for the content required in enforcement titles. The enforcement title must state the name of the court that issued the enforcement title, the case in which the enforcement title was issued, as well as the date of the judgment or ruling, which has to be executed. Also, enforcement titles must specify the time of entry into force of the decision or an indication that the decision is urgently enforceable and the time of issuance of the enforcement title. The enforcement title must also include the full names of both the creditor and the debtor and their addresses, personal identification codes, legal entity codes, details of credit, payment and/or electronic money institutions (if known). The enforcement title for the recovery of maintenance payments shall also specify the dates of birth of the children.

One of the most important requirements related to decisions which have to be executed is that the enforcement title must indicate literally the operative part of the judgment or ruling which has to be enforced. The requirement to specify the operative part of the decision literally to the enforcement title confirms that the

\footnotetext{
${ }^{20}$ ECtHR 06.03.2003, Case Jasiuniene v. Lithuania, No. 41510/98.

${ }^{21}$ The Supreme Court of Lithuania 16.09.2002, Case No. 3K-3-992/2002.
} 
enforcement title legitimizes only the enforcement process and not the validity of the claim. The validity of the claim being verified cannot be verified in the enforcement process (Višinskis and Stauskienè, 2007: 59). This position is in line with the idea of the court order procedure. When the court issues an enforcement title the court does not assess the merits of the claim and its validity. The court can refuse to issue a court order only if the claim is manifestly unfounded (Article 435 (2) of the CCP). The creditor has the obligation to indicate in the statement the evidence forming the basis of the claim.

The commencement of proceedings for the enforcement of the court order depends solely on the debtor's consent to the creditor's claim against him. However, an enforcement title may not be issued for the enforcement of any judgment, but rather only for an enforceable judgment. The enforcement of decisions (coercive measures) is not always required. Instead, it is only one form of enforcement. The concept of implementation is broader than the concept of enforcement. All court decisions are implemented, since all court decisions have some effect on the legal relationship between the parties (Višinskis and Ambrasienè, 2008: 40-41). However, decisions on recognition, termination, alteration or establishment of a legal relationship do not normally require enforcement, since the judgment itself has legal effect. A decision on the determination of the rights and obligations of the parties is effective from the moment of entry into force, regardless of whether the defendant has taken any action or not.

Meanwhile, the legal effect of judgments on an award 22 is achieved only when the defendant performs the acts which the court orders the defendant to take in the operative part of the judgment. A defendant who fails to perform the obligations ordered is subject to the methods of coercion provided by the law. Judgments that can enforced using coercive methods are called enforceable. Since court decisions deal not only with pecuniary claims, but also with others that cannot be subject to enforcement actions, a separate enforcement order is required to initiate enforcement proceedings. The enforcement order defines the limits of enforcement, not the judgment. According to Article 648 (6) of the CPP, if an error is made in the

\footnotetext{
22 Judgments on an award mean judgments ordering a certain amount of money of property from the debtor in favor of the creditor.
} 
issuance of an enforcement order, it shall be corrected by the issuing authority at the request of the party concerned.

According to Article 646 of the CCP, when issuing an enforcement order, the court does not resolve disputes between the parties but merely issues enforcement orders in accordance with enforceable court decisions. ${ }^{23}$ The court only verifies that the limitation period for the enforcement of the enforcement order has not expired and checks that there are no data on the execution of the decision and whether the judgment or part thereof is enforceable. Whether an enforcement order will be presented for enforcement to a bailiff depends on the will of the creditor (Kirkutis, and Višinskis, 2020: 79). It is one of the expressions of the principle of dispositivity in the enforcement proceeding (Žemkauskas, Kirkutis, and Višinskis, 2020: 515).

However, this does not mean that the enforcement title can be considered as a completely separate, independent document, isolated from the judgment (Stauskiene, 2007: 73). The basis for enforcement action is an enforcement title, but the legal basis for enforcement is always a court decision and not an enforcement title. ${ }^{24}$

The nature of an enforcement title proves that the content and quality requirements for court judgments and rulings also affects the content of enforcement title and the efficiency of the enforcement process.

\section{The role of the court in the enforcement process and the peculiarities of the enforcement of some decisions}

Section 1.2 of this article discussed the basic requirements for a court decision. However, in specific cases, the СCP also provides some requirements that are relevant to the enforcement process. Also, the CCP provides a possibility for the court to defer, set out or change the procedure for enforcing the judgment.

\footnotetext{
23 The Supreme Court of Lithuania 04.11.2015, Case No. 3 K-3-587-687/2015.

${ }^{24}$ The Supreme Court of Lithuania 22.05.2006, Case No. 3K-3-352/2006.
} 
Article 271 (1) of the CCP states that when making a judgment the court shall, if necessary, determine the specific procedures and terms for the execution of the judgment. When awarding property in a dispute about ownership, for example, the court must specify the value of the property to be awarded, which must be recovered from the defendant. ${ }^{25}$ The purpose of this requirement is to recover the value of the assets to the creditor if the enforcement proceedings reveal that the assets awarded no longer exist.

By way of another example, in a decision ordering the defendant to perform or terminate certain acts not involving the transfer of assets or funds, the court may in the same judgment state that if the defendant fails to comply within the time limit, the plaintiff has the right to perform those actions or take measures to terminate them at the defendant's expense and at the same time recover the necessary costs from the defendant. If the specified actions can be performed or terminated only by the defendant, or if the defendant is obliged to eliminate the consequences of construction in violation of legal requirements, the court shall set a time limit within which the judgment must be executed. In addition, the court must indicate the amount of the fine to be imposed on the defendant if he fails to comply with the judgment or to bring the specified action to an end within the period set in the judgment.

Article 771 (6) of the CCP states that in the absence of compliance with the decision obliging the debtor to perform or terminate certain actions, which can only be performed or terminated by the debtor himself, or the decision obliging the debtor to eliminate the consequences of construction in violation of legal requirements, or a mandatory order, or a mandatory order, for which time limits have not been set, then the bailiff shall forward the written act to the district court of the place where the bailiff's office is located. If the court determines that the debtor has not complied with the judgment or binding order, the court may impose a fine of up to three hundred euros for each day of delay in enforcing the judgment or binding order in favour of the creditor. The fines regulated in both Article 273 (3) and Article 771 (6) of the CCP are imposed on the same basis, i.e. for failure to fulfil an obligation of a

25 Article 272 of the CCP. 
similar nature. According to the case law, these fines are recovered in favour of the recoveree. ${ }^{26}$

Another important institution of the CCP impacting both the content of court decisions and the enforcement process is a possibility for the court to defer, establish or change the procedure of enforcing the judgment. According to Article 284 of the CCP, the court has a right, at the request of the persons participating in the case or on its own initiative, to postpone or set out the execution of the decision, as well as to change the procedure for execution of the decision, taking into account the property situation or other circumstances of both parties. If the amounts required for the execution of a court decision awarding monies from the State of Lithuania are not provided for in the approved state budget, the execution of this decision may be postponed to the next budget year at the request of the defendant. However, an execution of an urgent decision or part thereof may not be postponed.

These requirements help ensure that in cases where execution upon the judgment depends on actions by the debtor, the judgment can be adequately enforced. These requirements encourage the debtor to comply with the judgment, since the court may determine by the terms in the judgment itself that a certain fine is levied for each day the judgment goes unenforced. If these issues have not been resolved by the court judgment, they still may be considered after the judgment has been announced. This institution is an exception to the general rule of the CCP that all final court decisions are binding.

A judgment may not always be enforceable in accordance with the procedure specified therein. There are numerous reasons why a judgment might not be enforced. The debtor might act dishonestly to avoid enforcement of the judgment. The judgment ordering the defendant to take or terminate certain actions might itself be deficient by failing to indicate the consequences of non-enforcement, such as not including specific sanctions such as monetary penalties. Furthermore, other objective circumstances may prevent enforcement. The case-law recognizes a ground for changing the procedure for the enforcement of a judgment where the defendant has been ordered by a judgment to take or terminate certain acts, but the

\footnotetext{
${ }^{26}$ The Supreme Court of Lithuania 12.06.2019, Case No. e3K-3-213-248/2019.
} 
judgment has not specified the consequences of non-compliance. ${ }^{27} \mathrm{~A}$ change or modification in the procedure for enforcement of a judgment also is warranted in situations where the execution of a decision on the return of property in kind (restitution in kind) has revealed that the property (or part of it) is no longer in kind and it is accordingly impossible to enforce the decision to return the property. ${ }^{28}$

In such cases, the parties to the case have the right to request the court to change the procedure for enforcement of the decision in accordance with Article 284 (1) of the CCP. A change in the procedure for the enforcement of a judgment is the introduction of a different procedure for the enforcement of a judgment from that set out in the operative part of the judgment or the normal procedure for the enforcement of certain types of judgment. ${ }^{29}$ The change of the procedure for enforcement of the judgment ensures the binding effect and enforceability of the final judgment is the protection of the legitimate interests of the party. Since the application for a change in the procedure for the enforcement of a judgment is pending after the judgment's entry into force, the court is bound by the content of the substantiated substantive claim set out in the operative part of the judgment and cannot change the substance of the judgment. The mechanism for changing the procedure for the enforcement of the judgment is not intended to be used for reviewing/modifying (the substance of a court judgment that has entered into force. When modifying the procedure for enforcement of a judgment, the court therefore may not extend or reduce the rights or obligations established by the parties and granted by the judgment or create obligations for persons other than those specified in the court judgment whose enforcement procedure is changed (except their successors), etc. 30

In conclusion, the above-mentioned shows the importance of the requirements of court judgments to the enforcement proceeding. These requirements ensure the effectiveness of the enforcement proceeding and the protection of the violated rights of the individual in the shortest possible time.

\footnotetext{
${ }^{27}$ The Supreme Court of Lithuania 13.02.2006, Case No. 3K-7-29/2006.

${ }_{28}$ The Supreme Court of Lithuania 12.12.2014, Case No. 3K-3-545/2014 and the Supreme Court of Lithuania 19.04.2017, Case No. e3K-3-201-611/2017.

${ }^{29}$ The Supreme Court of Lithuania 04.01.2013, Case No. 3K-7-83/2013.

30 The Supreme Court of Lithuania 25.06.2013, Case No. 3K-3-346/2013.
} 


\section{Conclusions}

1. The court order in Lithuania itself is an enforcement title due to the limitations of this procedure. Only pecuniary claims for a judgment can be settled by court order procedure. Therefore, the court order has to meet the requirements for the enforcement title.

2. In Lithuania, court decisions consist of four parts: introductory, descriptive, motivational and operative. As these parts are inter-related, they ensure that a court decision is one, legal, integrated act. At the time of announcement of the decision, it must consist of all four parts.

3. The operative part of the court judgment is the most important for the enforcement procedure. It must be transposed literally into the enforcement order. It is the operative part of the judgment that determines the scope of the enforcement proceedings. Thus, this paragraph must be clear and enforceable, without any ambiguity.

4. Standards of Quality of Court Decisions set out 7 principles for the quality of court decisions that are recommended to be followed when preparing judgments or rulings. Although Standards are not binding, they are applied by the courts of Lithuania and have led to a harmonized form of court decisions.

5. All court decisions produce legal effects, as all court decisions have some effect on the legal relationship between the parties. However, not all court decisions require enforcement (e.g., application of coercive measures). The enforceability of a judgment depends on the legal relationship between the dispute and the content of the claims. Decisions on recognition, termination, alteration or establishment of a legal relationship do not normally require enforcement, as the judgment itself has legal effect (constitutive judgment).

\section{References}

Kirkutis, M., and Višinskis, V. (2020) Antstolių institucinès veiklos pokyčiai (Vilnius, Mykolo Romerio universitetas), Lietuvos teisè 2020: esminiai pokyčiai (II dalis).

Stauskiené, E. (2007) Teisine vykdymo proceso prigimtis (Vilnius, Mykolo Romerio universitetas), Jurisprudencija 1(97).

Višinskis, V., and Abrasienè, D. (2008) Teismo vykdomujų dokumentų išdavimo tvarka (Vilnius, Mykolo Romerio universitetas), Jurisprudencija 2(104).

Višinskis, V., and Stauskienè, E. (2007) Teismo išduodami vykdomieji dokumentai (Vilnius, Mykolo Romerio universitetas), Jurisprudencija 11(101). 
Žemkauskas, M., Kirkutis, M., and Višinskis, V. (2020) Bendrujų civilinio proceso principų taikymas vykdymo procese (Vilnius, Mykolo Romerio universitetas), Jurisprudencija 2(27).

\section{About the authors}

Mykolas Kirkutis is a Ph.D. candidate at Mykolas Romeris University in Vilnius, Lithuania, e-mail: mkirkutis@gmail.com.

Remigijus Jokubauskas is a Ph.D researcher at Mykolas Romeris University in Vilnius, Lithuania and a consultant of the Council of Europe, e-mail: remigijus@jokubauskas.org.

Dr. Darius Bolzanas is a lecturer at Mykolas Romeris univeristy, Lithuania, e-mail: darius.bolzanas@gmail.com.

Prof. dr. Vigintas Višinskis is a professor at Mykolas Romeris University in Vilnius, Lithuania and a judge at the Court of Appeal of Lithuania, e-mail: vigvis@gmail.com. 